\title{
Reproductive biology of the brown smooth-hound shark, Mustelus henlei (Chondrichthyes: Triakidae), off northwestern Mexico based on macroscopic and histological analyses
}

\section{Biología reproductiva del tiburón mamón Mustelus henlei (Chondrichthyes: Triakidae) frente al noroeste de México basada en análisis macroscópico e histológico}

\author{
Katherin Soto-López ${ }^{1}$, Rosa I Ochoa-Báez ${ }^{1}$, Javier Tovar-Ávila², Felipe Galván-Magaña ${ }^{1 *}$ \\ ${ }^{1}$ Instituto Politécnico Nacional (IPN). Centro Interdisciplinario de Ciencias Marinas (CICIMAR), La Paz, \\ Baja California Sur, Mexico, Ave. Instituto Politécnico Nacional s/n, Colonia Playa Palo de Santa Rita, \\ CP 23096, La Paz, Baja California Sur, Mexico. \\ 2 Centro Regional de Investigación Pesquera en Bahía de Banderas, Instituto Nacional de Pesca, Calle Tortuga 1, \\ La Cruz de Huanacaxtle, CP 63732, Bahía de Banderas, Nayarit, Mexico.
}

* Corresponding author. E-mail: galvan.felipe@gmail.com

\begin{abstract}
The brown smooth-hound shark Mustelus henlei is one of the most abundant species caught by the artisanal elasmobranch fishery off northwestern Mexico. The present study estimates the reproductive parameters for M. henlei using, for the first time, histological analysis and survey data collected from May 2008 to May 2016. Mustelus henlei was reported in the landings from February to November each year $(n=1,469)$. Total length $\left(T_{L}\right)$ varied between 450 and $1,530 \mathrm{~mm}$ (average $\left.=753 \mathrm{~mm}, \mathrm{SD}=111\right)$. The sex ratio (male:female) was similar to the 1:1 ratio. Gravid females were caught during April, August, and November. Average fecundity was 9 . Length at maturity was 656 mm $\mathrm{T}_{\mathrm{L}}$ for females and $636 \mathrm{~mm} \mathrm{~T}_{\mathrm{L}}$ for males, and length at maternity, estimated for the first time for this species, was $676 \mathrm{~mm} \mathrm{~T}_{\mathrm{L}}$. The first phases of spermatogenesis and oogenesis were identified through histological analysis of gonads from immature individuals. Semen storage was detected in the oviducal gland of females at the terminal zone, whereas in males spermatozeugmata was detected in the seminal vesicles. According to the species reproductive parameters, $M$. henlei can be categorized as a species of high biological productivity among elasmobranchs and can thus support certain level of fishing pressure off northwestern Mexico if adequate fishing management and regulatory measures are employed. Some of the reproductive parameters that were estimated for this species in the present study were different from those estimated for other stocks from Mexican and United States waters.
\end{abstract}

Key words: reproduction, length at maturity, length at maternity, semen storage, Mustelus henlei.

RESUMEN. El tiburón mamón Mustelus henlei es una de las especies más abundantes en las capturas de la pesca artesanal de elasmobranquios frente al noroeste de México. En el presente estudio se estimaron los parámetros reproductivos usando, por primera vez, análisis histológicos y datos de campo recolectados de mayo de 2008 a mayo de 2016. Mustelus henlei fue registrada en los desembarques de febrero a noviembre de cada año $(n=1,469)$. La longitud total $\left(\mathrm{L}_{\mathrm{T}}\right)$ varió entre 450 y $1,530 \mathrm{~mm}$ (promedio $=753 \mathrm{~mm}$, desviación estándar $\left.=111\right)$. La proporción sexual (macho:hembra) fue similar a 1:1. Se encontraron hembras grávidas en abril, agosto y noviembre. La fecundidad promedio fue de 9 crías. La talla de madurez fue de $656 \mathrm{~mm} \mathrm{~L}_{\mathrm{T}}$ para las hembras y de $636 \mathrm{~mm} \mathrm{~L}_{\mathrm{T}}$ para los machos, y la talla de maternidad, estimada por primera vez para la especie, fue de $676 \mathrm{~mm} \mathrm{~L}$. Se identificaron las primeras fases de la espermatogénesis y ovogénesis a través del análisis histológico de las gónadas en individuos inmaduros. Se encontró almacenamiento de esperma en la glándula oviducal de las hembras a nivel de la zona terminal, mientras que en los machos se encontró espermatozeugmata dentro de la vesícula seminal. Con base en sus parámetros reproductivos, $M$. henlei puede ser categorizada como una especie con alta productividad biológica entre los elasmobranquios y, por tanto, podría soportar ciertos niveles de presión por pesca en aguas frente al noroeste de México con un manejo pesquero y medidas de regulación adecuadas. Algunos de los parámetros reproductivos estimados para la especie en el presente estudio mostraron diferencias con aquellos estimados para otras poblaciones en aguas mexicanas y de Estados Unidos.

Palabras clave: reproducción, talla de madurez, talla de maternidad, almacenamiento de esperma, Mustelus henlei.

\section{INTRODUCTION}

The brown smooth-hound shark, Mustelus henlei (Gill $1863)$, is the second most caught species in the artisanal elasmobranch fishery on the west coast of Baja California Sur (BCS, Mexico) (Furlong-Estrada et al. 2017). Genetic studies

\section{INTRODUCCIÓN}

El tiburón mamón Mustelus henlei (Gill 1863) es la segunda especie de mayor captura en la pesquería artesanal de elasmobranquios en la costa occidental de Baja California Sur (BCS, México) (Furlong-Estrada et al. 2017). De 
have shown that there are probably 5 subpopulations of this species in Mexican waters, 3 in the Gulf of California and 2 off the west coast of the Baja California Peninsula (Sandoval-Castillo and Beheregaray 2015); however, only the reproductive biology of the stock in the northern Gulf of California region has been studied to date.

Despite the natural abundance and diversity of elasmobranchs on the Pacific coasts of Mexico and the low-tech fishing gear used by the small-scale elasmobranch fishery off northwestern Mexico, the risk of stock overexploitation remains a problem due to the low rate of stock renewal in elasmobranchs. This condition makes elasmobranchs vulnerable even at moderate levels of fishing mortality (Musick 1999).

In Mexico, several elasmobranch conservation strategies have been implemented. In 2006, the Official Mexican Standard 029 was published to establish guidelines for the use of elasmobranchs, banning finning and promoting the protection of several endangered species along the Mexican coasts (DOF 2007). To regulate fishing mortality and protect the recruitment and critical habitat of elasmobranchs, this standard stablished fishery closures, which have been implemented, since 2012, from 1 May to 31 July in the Pacific Ocean, from 1 May to 30 June in the Gulf of Mexico, and from 1 May to 30 June and 1 to 30 August in the Bank of Campeche (DOF 2007).

The resilience of a stock can be associated with the reproductive biology of the species; species with short reproductive cycles and high fecundity can support higher rates of exploitation (Walker 1998). To achieve adequate fishing management of $M$. henlei, it is necessary to know the reproductive parameters of all the stocks (Saïdi et al. 2009). Some reproductive parameters (fecundity, length at maturity, and gestation period) of $M$. henlei in the Gulf of California and on the coast of California have been described, with differences between both stocks (Yudin and Cailliet 1990, Pérez-Jiménez and Sosa-Nishizaki 2008). The variation of reproductive parameters between different stocks has also been reported for other Mustelus species, for example, Mustelus antarcticus in Australia (Walker 2007) and Mustelus manazo in Japan and Taiwan (Yamaguchi et al. 2000). These variations are attributed to differences in environmental conditions and must be considered in stock assessment and the development of management strategies.

The objective of this study is to present, for the first time, information on the reproductive biology of $M$. henlei off the west coast of BCS based on macroscopic and histological analyses and to compare it with existing information on the neighboring stocks. This information is expected to contribute to the development and improvement of the management measures recently established for the elasmobranch fishery in Mexico.

\section{MATERIALS AND METHODS}

Field sampling was performed from May 2008 to May 2016 at 4 artisanal fishing camps along the west coast of acuerdo con estudios genéticos, en aguas mexicanas existe la probabilidad de que hayan 5 subpoblaciones de esta especie, 3 dentro del golfo de California y 2 en las costas occidentales de la península de Baja California (Sandoval-Castillo y Beheregaray 2015); sin embargo, solo se ha estudiado la biología reproductiva de la población de la parte norte del golfo de California.

A pesar de la abundancia natural y diversidad de elasmobranquios en las costas mexicanas del Pacífico y de la baja tecnología de pesca empleada por la pesquería de pequeña escala de elasmobranquios que opera frente al noroeste de México, el riesgo de sobreexplotación de las poblaciones sigue siendo un problema debido a la baja tasa de renovación de los elasmobranquios. Esta condición hace vulnerables a los elasmobranquios incluso a niveles moderados de mortalidad por pesca (Musick 1999).

En México, varias estrategias han sido implementadas para la conservación de elasmobranquios. En 2006 se publicó la Norma Oficial Mexicana 029 para establecer lineamientos para el uso de elasmobranquios, y en ella se prohíbe el aleteo y se promueve la protección de varias especies amenazadas en las costas mexicanas (DOF 2007). Para regular la mortalidad por pesca y proteger el reclutamiento y el hábitat crítico de elasmobranquios, en la norma se establecen vedas que, desde 2012, se han estado implementando del 1 de mayo al 31 de julio en el océano Pacífico y del 1 de mayo al 30 de junio en el golfo de México y del 1 de mayo al 30 de junio y del 1 al 30 de agosto para el área del banco de Campeche (DOF 2007).

La resiliencia de una población a la pesca está relacionada con su productividad biológica, y las especies que poseen ciclos reproductivos cortos y fecundidad alta podrían soportar mayores tasas de explotación (Walker 1998). Para lograr una gestión adecuada de la pesca de $M$. henlei, es necesario conocer los parámetros reproductivos de todas las poblaciones (Saïdi et al. 2009). Algunos parámetros reproductivos (fecundidad, talla de madurez y periodo de gestación) de la especie en el golfo de California y en la costa de California han sido descritos, con diferencias entre estas poblaciones (Yudin y Cailliet 1990, Pérez-Jiménez y Sosa-Nishizaki 2008). Para diferentes especies del género Mustelus, se ha reportado la variación en los parámetros reproductivos entre distintas poblaciones, como Mustelus antarcticus en Australia (Walker 2007) y Mustelus manazo en Japón y Taiwán (Yamaguchi et al. 2000). Estas variaciones son atribuidas a diferencias en las condiciones ambientales, y es importante considerarlas en la evaluación de las poblaciones y en el desarrollo de estrategias de manejo.

El objetivo del presente estudio es presentar, por primera vez, información sobre la biología reproductiva de M. henlei en la costa occidental de BCS basada en un análisis macroscópico e histológico, además de compararla con información de las poblaciones aledañas ya descritas. Se espera que esta información contribuya al desarrollo y mejora de las medidas de manejo establecidas recientemente para las pesquerías de elasmobranquios en México. 
BCS (Mexico): Punta Lobos to the south, San Lazaro and San Ignacio in the central region, and Bahía Tortugas to the north (Fig. 1). Individuals were identified by examination of tooth and dorsal fin features following the guide by Compagno et al. (2005); M. henlei has high-cusped "pavement" teeth, and its trailing dorsal fin edges appear broadly frayed with dark margins of bare ceratotrichia.

Total length $\left(T_{L}\right)$ of each reported shark was measured, to the closest millimeter, from the tip of the snout to the end of the caudal fin, with the caudal fin extended. Sex was determined by the presence of claspers in male sharks, and clasper length was obtained by measuring, to the closest millimeter, the distance from the base to the tip of the claspers.

Males were considered mature if their claspers were completely calcified and articulate at the base with a $180^{\circ}$ rotation (pers. obs., Hamlett 2005). Females were considered mature if they had oocytes measuring $>6 \mathrm{~mm}$ and had completely developed oviducal glands or embryos or eggs in the uterus (pers. obs., Conrath and Musick 2002). The reproductive system of each organism was removed and fixed in $10 \%$ formaldehyde. Only reproductive systems with proper fixation were used for histological processing.

Student's t tests were performed to check for significant differences in $T_{L}$ between sexes and between development stages (mature and immature). The composition and temporal variation of sizes were analyzed with frequency histograms. Sex ratio was compared with a 1:1 ratio via a $\chi$-squared test.

Histological sections of ovaries and testicles were made to determine maturity stages and to describe oogenesis and

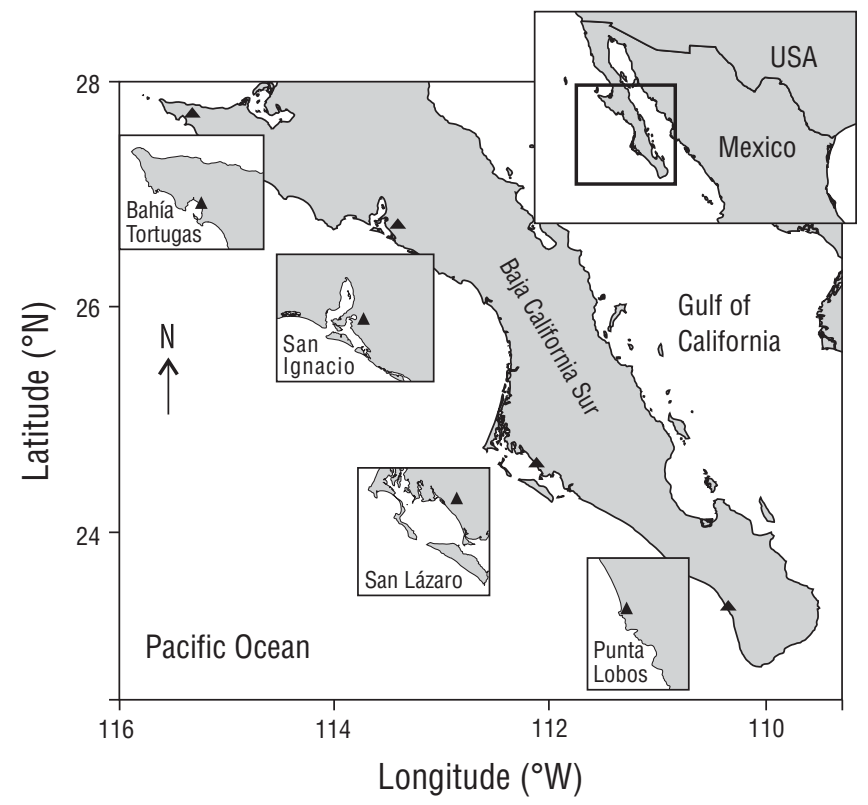

Figure 1. Sampling locations (triangles) on the west coast of Baja California Sur.

Figura 1. Zonas de muestreo (triángulos) a lo largo de la costa occidental de Baja California Sur.

\section{MATERIALES Y MÉTODOS}

Se realizaron muestreos de mayo de 2008 a mayo de 2016 en 4 campos pesqueros artesanales a lo largo de la costa occidental de BCS (México): punta Lobos en la zona sur, San Lázaro y San Ignacio en la zona centro y bahía Tortugas en la zona norte (Fig. 1). Los organismos fueron identificados con base en las características de los dientes y de la aleta dorsal usando la guía de campo de Compagno et al. (2005); M. henlei presenta dientes "pavimentados" en forma de cúspide alta, y los bordes posteriores de las aletas dorsales aparecen deshilachados con márgenes oscuros de ceratotrichia.

La longitud total $\left(\mathrm{L}_{\mathrm{T}}\right)$ de cada tiburón reportado se midió, al milímetro más cercano, desde la punta de la nariz hasta la punta de la aleta caudal, con la aleta caudal en su máxima extensión. Se identificó el sexo por la presencia de gonopterigios en los machos, y la longitud de los gonopterigios se obtuvo midiendo, al milímetro más cercano, la distancia desde la base del gonopterigio hasta la punta.

Se consideraron machos maduros aquellos individuos que presentaban los gonopterigios completamente calcificados y articulados desde su base, con rotación de $180^{\circ}$ (obs. pers., Hamlett 2005). Las hembras fueron consideradas maduras si presentaban ovocitos que midieran $>6 \mathrm{~mm}$ y glándulas oviducales completamente desarrolladas, así como embriones o huevos en el útero (obs. pers., Conrath y Musick 2002). El aparato reproductor de cada individuo fue extraído y fijado en formol al $10 \%$. Solamente los aparatos reproductivos que presentaron una correcta fijación fueron usados para el procesamiento histológico.

Se aplicaron pruebas $t$ de Student para comprobar si existían diferencias significativas en la $\mathrm{L}_{\mathrm{T}}$ entre ambos sexos y entre los estadios de madurez (maduro e inmaduro). La composición y la variación temporal de las tallas se analizaron mediante histogramas de frecuencia. La proporción de sexos fue comparada con una proporción de 1:1 mediante una prueba de $\chi$-cuadrada.

Se realizaron cortes histológicos de los ovarios y testículos para determinar los estadios de madurez y describir la ovogénesis y la espermatogénesis utilizando la clasificación de Serra-Pereira et al. (2011). Se realizaron secciones histológicas de la glándula oviducal y la vesícula seminal para determinar la posibilidad de almacenamiento de esperma. La técnica de tinción de Mallory fue aplicada al ovario para ayudar en la identificación de colágeno y las fibras de reticulina, y la técnica del ácido periódico-Schiff fue aplicada a la glándula oviducal para la identificación de polisacáridos, mucopolisacáridos, mucoproteínas, glicoproteínas y mucinas. Finalmente, la técnica de Feulgen fue utilizada para la identificación del ácido desoxirribonucleico de los espermatozoides en los testículos y la vesícula seminal (Pearse 1968, Humason 1979).

La talla de madurez $\left(\mathrm{L}_{50}\right)$ para cada sexo y la talla de maternidad $\left(\mathrm{L}_{\mathrm{m} 50}\right)$ se estimaron mediante la ecuación logística $P m=1 /\left[1+\mathrm{e}^{-\left(\mathrm{a}+\mathrm{b} \times \mathrm{L}_{\mathrm{r}}\right.}\right]$, donde $a$ y $b$ son parámetros y $P m$ es 
spermatogenesis using the classification by Serra-Pereira et al. (2011). Histological sections of the oviducal glands and seminal vesicles were made to determine the possibility of semen storage. The Mallory staining technique was applied for the ovaries because it helped identify collagen and reticulin, and the periodic acid-Schiff technique was applied in the case of oviducal glands to identify polysaccharides, mucopolysaccharides, mucoproteins, glycoprotein, and mucins. Finally, the Feulgen technique was used to identify deoxyribonucleic acid of spermatozoa in the testicles and the seminal vesicles (Pearse 1968, Humason 1979).

Length at maturity $\left(\mathrm{L}_{50}\right)$ for each sex and length at maternity $\left(\mathrm{L}_{\mathrm{m} 50}\right)$ were calculated using the logistic equation $P m=1 /\left[1+\mathrm{e}^{-\left(\mathrm{a}+\mathrm{b} \times \mathrm{T}_{\mathrm{L}}\right.}\right]$, where $a$ and $b$ are parameters and $P m$ is the sexual ratio of mature specimens in the sample (binomial variable). To determine the parameters of logistic equations, mature sharks were assigned a maturity condition value of 1 , and immature sharks were assigned a maturity condition value of 0 (Mollet et al. 2000, Walker 2007). The proportion of the population of pregnant females at any $T_{L}$ was determined by classifying each female into female with "maternal condition" (carrying embryos or eggs in the uterus that would contribute to recruitment in the following year) or with "non-maternal condition" and by assigning a 1 or 0 value, respectively (Mollet et al. 2000, Walker 2007). $\mathrm{L}_{50}$ is defined as the size at which $50 \%$ of the population is mature, and $\mathrm{L}_{\mathrm{m} 50}$ is the size at which $50 \%$ of females are pregnant and will contribute to the following cohort (Walker 2005a). $\mathrm{L}_{\mathrm{m} 50}$ was not analyzed by season because most pregnant females were caught in August (95\%), all with small-sized embryos; thus, $\mathrm{L}_{\mathrm{m} 50}$ represents the proportion of females that will contribute to the cohort of the following year.

The length and width of testicles and oviducal glands were measured to the nearest millimeter after fixation. The width of both organs was taken by the longest transverse section. The relationship between $T_{L}$ and the length of the testicles and width of the oviducal glands was analyzed to determine the onset at which these organs increase in size; in the case of oviducal glands, this relationship was analyzed for each of the development stages (immature, mature, and pregnant).

The number of embryos in each pregnant female was quantified to estimate average fecundity. Size at birth was calculated at the midpoint between the maximum size of embryos and the minimum size of free-living organisms with open umbilical scars. Birth season and gestation period were determined by the size of the embryos, maximum diameter of oocytes, and presence of newborns throughout the year.

\section{RESULTS}

A total of 1,469 M. henlei individuals (715 males and 754 females) were analyzed. The sex ratio $(1.05 \mathrm{~F}: 1.00 \mathrm{M})$ was not significantly different from 1:1 $\left(\chi^{2}=1.03, P>0.05\right)$ (Table 1$)$. Mustelus henlei was recorded in landings from February to November each year (except from May to July after 2012, la proporción sexual de especímenes maduros de la muestra (variable binomial). Para la determinación de los parámetros de la ecuación logística, los organismos maduros fueron asignados una condición de madurez de valor 1 y, a su vez, los organismos inmaduros fueron asignados a una condición de madurez de valor 0 (Mollet et al. 2000, Walker 2007). La proporción de la población de hembras preñadas a cualquier $\mathrm{L}_{\mathrm{T}}$ se determinó clasificando a cada hembra en hembra bajo "condición materna" (con embriones o huevos en el útero que pudieran contribuir al reclutamiento del siguiente año) o bajo "condición no materna" y asignando un valor de 1 o 0 , respectivamente (Mollet et al. 2000, Walker 2007). La $\mathrm{L}_{50}$ es definida como la talla a la cual el $50 \%$ de la población se encuentra madura, y la $\mathrm{L}_{\mathrm{m} 50}$ es la talla a la cual el $50 \%$ de las hembras se encuentran preñadas y contribuirán a la siguiente cohorte (Walker 2005a). $\mathrm{L}_{\mathrm{m} 50}$ no fue analizada por temporada, ya que la mayoría de las hembras preñadas fueron capturadas en agosto $(95 \%)$, todas con embriones de talla pequeña; $\mathrm{L}_{\mathrm{m} 50}$ representa, entonces, la proporción de hembras que contribuirán a la cohorte el siguiente año.

La longitud y el ancho de los testículos y la glándula oviducal fueron medidos al milímetro más cercano después de la fijación. El ancho de ambos órganos fue tomado de la sección transversal más amplia. Se analizó la relación entre la $\mathrm{L}_{\mathrm{T}}$ y el largo de los testículos y el ancho de la glándula oviducal para determinar la talla a la cual estos órganos incrementan su tamaño; para el caso de la glándula oviducal, esta relación se analizó para cada una de las etapas de madurez (inmaduro, maduro y preñada).

Se cuantificó el número de embriones presentes en cada hembra preñada para estimar la fecundidad promedio. La talla de nacimiento se estimó a partir del punto medio entre el tamaño máximo registrado de los embriones y la talla mínima de los organismos de vida libre con cicatriz umbilical abierta. La temporada de nacimiento y el periodo de gestación se estimaron por medio de la talla de los embriones, el diámetro máximo de los ovocitos y la presencia de neonatos a lo largo del año.

\section{RESUltados}

Un total de 1,469 organismos fueron analizados (715 machos y 754 hembras). La proporción sexual (1.05H:1.00M) no presentó diferencias significativas con respecto a la proporción 1:1 $\left(\chi^{2}=1.03, P>0.05\right)$ (Tabla 1). Mustelus henlei fue registrada en las capturas de febrero a noviembre de cada año (excepto de mayo a julio después de 2012 debido al periodo de veda establecido para las aguas mexicanas del Pacífico), con variación estacional entre las distintas zonas de muestreo; fue común en los primeros meses del año en la zona sur, a mediados del año en la zona centro y al final del año en la zona norte.

Las tallas de los individuos oscilaron entre 450 y $1,530 \mathrm{~mm} \mathrm{~L}_{\mathrm{T}}$ (promedio $=753 \mathrm{~mm}$, desviación estándar $[\mathrm{DE}]=$ 111). Las hembras presentaron mayor talla $\left(1,530 \mathrm{~mm} \mathrm{~L}_{\mathrm{T}}\right)$ 
because of the fishing closure period established for Mexican Pacific waters), with seasonal variations between the different sampling zones; it was common in the southern region during the first months of the year, in the central region during the middle part of the year, and in the northern region at the end of the year.

The length of individuals varied between 450 and $1,530 \mathrm{~mm} \mathrm{~T}_{\mathrm{L}}$ (average $\left.=753 \mathrm{~mm}, \mathrm{SD}=111\right)$. Females were larger $\left(1,530 \mathrm{~mm} \mathrm{~T}_{\mathrm{L}}\right)$ than males $\left(1,160 \mathrm{~mm} \mathrm{~T}_{\mathrm{L}}\right)$, though no significant differences were found between the average $T_{L}$ of both sexes (Student's $t_{0.05,1,469}=-14.93$ ) (Fig. 2). Around 11\% of measured sharks surpassed the maximum $T_{L}$ reported in previous studies.

The gonads of 685 organisms (401 males and 284 females) were analyzed to identify maturity stages by examination of macroscopic characteristics and histological analysis. All immature male specimens of $M$. henlei analyzed in the present study had no articulate (rotation) claspers, but all mature individuals had calcified, rotating claspers. The rotation of claspers alone was not considered evidence of maturity unless claspers were fully calcified. Immature males and females measured between 450 and $810 \mathrm{~mm} \mathrm{~T}_{\mathrm{L}}$. Mature males and females measured more than $610 \mathrm{~mm} \mathrm{~T}_{\mathrm{L}}$ and accounted for $85.8 \%$ of all measured specimens. No significant differences were found between the sizes of both sexes by maturity stage (Student's $t_{0.05,98}=-0.59$ for immature specimens and Student's $t_{0.05,-13.89}=-0.59$ for mature specimens). Pregnant females larger than $650 \mathrm{~mm} \mathrm{~T}_{\mathrm{L}}$ were recorded in April, May, August, and November and represented $41 \%$ of total reported females (Fig. 3). Estimated $\mathrm{L}_{50}$ for males $\left(635 \mathrm{~mm} \mathrm{~T}_{\mathrm{L}}, \mathrm{SD}=\right.$ 6.03) was slightly lower than that for females $\left(657 \mathrm{~mm} \mathrm{~T}_{\mathrm{L}}\right.$, $\mathrm{SD}=7.43$ ). Estimated $\mathrm{L}_{\mathrm{m} 50}$ for the northwestern coast of BCS (where most pregnant females were caught) was $670 \mathrm{~mm} \mathrm{~T}$ ( $\mathrm{SD}=9.8$ ) (Fig. 4), slightly larger than the female $\mathrm{L}_{50}$, as expected.

The female reproductive system includes only one functional ovary. Histological analysis of immature female gonads revealed the first phases of oogenesis, with small oocytes (average diameter $=2 \mathrm{~mm}$ ) defined by the follicular epithelium and a poorly differentiated granular layer (Fig 5a). Mature females had large oocytes (diameter range $=6-12 \mathrm{~mm}$,

Table 1. Sex ratio (F:M) for Mustelus henlei at 4 artisanal fishing camps in Baja California Sur.

Tabla 1. Proporción sexual (H:M) para Mustelus henlei en 4 campos pesqueros de Baja California Sur.

\begin{tabular}{lccc}
\hline Fishing camp & Females & Males & Sex ratio \\
\hline Punta lobos & 374 & 310 & $1.2: 1.0$ \\
San Lázaro & 138 & 330 & $0.4: 1.0$ \\
San Ignacio & 22 & 47 & $0.4: 1.0$ \\
Bahía tortugas & 220 & 28 & $7.8: 1.0$ \\
\hline
\end{tabular}

con respecto a los machos $\left(1,160 \mathrm{~mm}\right.$ de $\left.\mathrm{L}_{\mathrm{T}}\right)$, sin haber diferencias significativas entre la $\mathrm{L}_{\mathrm{T}}$ promedio de ambos sexos $\left(t_{0.05,1,469}\right.$ de Student $\left.=-14.93\right)$ (Fig. 2). Alrededor del 11\% de los organismos muestreados sobrepasaron la $\mathrm{L}_{\mathrm{T}}$ máxima reportada en estudios previos.

Se analizaron las gónadas de 685 organismos (401 machos y 284 hembras) para identificar el estadio de madurez con base en sus características macroscópicas y el análisis histológico. Todos los ejemplares de machos inmaduros de M. henlei analizados en el presente estudio no tenían articulados (rotación) los gonopterigios, pero todos los individuos maduros tenían gonopterigios calcificados capaces de rotar. La rotación de los gonopterigios no se consideró por sí misma como evidencia de madurez, sino sólo en conjunto con la condición de calcificación completa. Las hembras y los machos inmaduros presentaron tallas de $450-810 \mathrm{~mm} \mathrm{~L}_{\mathrm{T}}$. Las hembras y los machos maduros presentaron tallas mayores que los $610 \mathrm{~mm} \mathrm{~L}_{\mathrm{T}}$ y representaron el $85.8 \%$ del total de los organismos registrados. No se encontraron diferencias significativas entre la talla de ambos sexos por estadios de madurez $\left(t_{0.05,98}\right.$ de Student $=-0.59$ para individuos inmaduros y $t_{0.05,-13.89}$ de Student $=-0.59$ para individuos maduros). Se registraron hembras preñadas a partir de $\operatorname{los} 650 \mathrm{~mm} \mathrm{~L} \mathrm{~L}_{\mathrm{T}}$ en abril, mayo, agosto y noviembre, y estas representaron el $41 \%$ del total de las hembras registradas (Fig. 3). La $\mathrm{L}_{50}$ estimada para los machos $\left(635 \mathrm{~mm} \mathrm{~L}_{\mathrm{T}}, \mathrm{DE}=6.03\right)$ fue ligeramente menor que para las hembras $\left(657 \mathrm{~mm} \mathrm{~L}_{\mathrm{T}}, \mathrm{DE}=7.43\right)$. La $\mathrm{L}_{\mathrm{m} 50}$ estimada para la costa noroccidental de BCS (donde la mayoría de las hembras preñadas fueron capturadas) fue

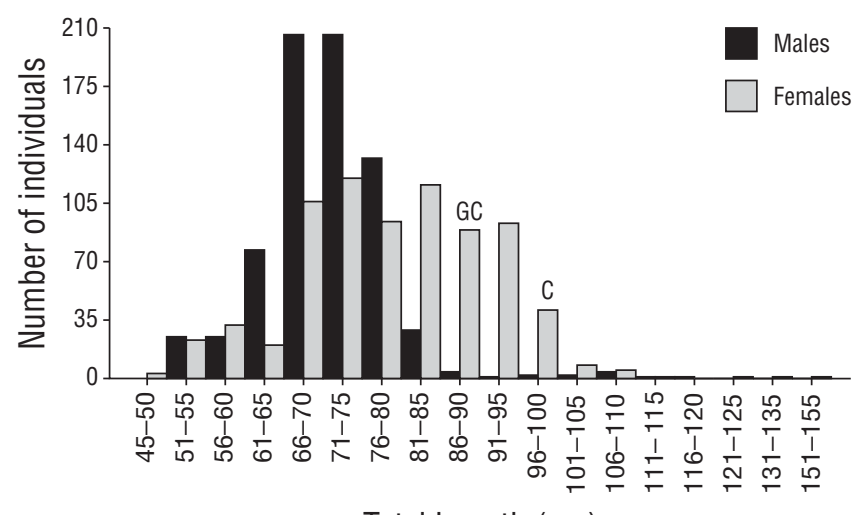

Total Length $(\mathrm{cm})$

Figure 2. Distribution of length by sex for Mustelus henlei caught in artisanal fisheries off the west coast of Baja California Sur, Mexico, from May 2008 to May 2016. GC = maximum reported size for the population in the northern Gulf of California region, $\mathrm{C}=$ maximum reported size for the California population.

Figura 2. Distribución de tallas por sexo para Mustelus henlei capturado en los campos pesqueros artesanales de la costa occidental de Baja California Sur, México, de mayo de 2008 a mayo de 2016. GC = talla máxima reportada para la población del norte del golfo de California, $\mathrm{C}=$ talla máxima reportada para la población de California. 
average $=9 \mathrm{~mm}$ ), with the follicular epithelium differentiated by 4 layers (from the inside to the outside): pellucid zone, granular layer, basal surface, and the theca cells (Fig. 5b). Maximum oocyte diameter was recorded in April (Fig. 6).

Oviducal glands of immature females measured 3-8 mm long and $<10 \mathrm{~mm}$ wide, whereas oviducal glands of mature females were $10-15 \mathrm{~mm}$ long and $10-20 \mathrm{~mm}$ wide. No relation was found between oviducal gland width and $T_{L}$ for any development stage (immature, mature, and pregnant; $r^{2}=$ $0.27,0.07$, and 0.008 , respectively; $P<0.05$ ). Four characteristic zones were identified in the histological sections of the oviducal glands: club zone, papillary zone, baffle zone, and terminal zone (Hamlett et al. 2002, Hamlett 2005); these sections had a simple ciliated columnar epithelium with acini formed by ciliated cells and secreting cells. The presence of semen was detected (April) in the terminal zone, forming conglomerates at the center of the acini (Fig. 5c, d).

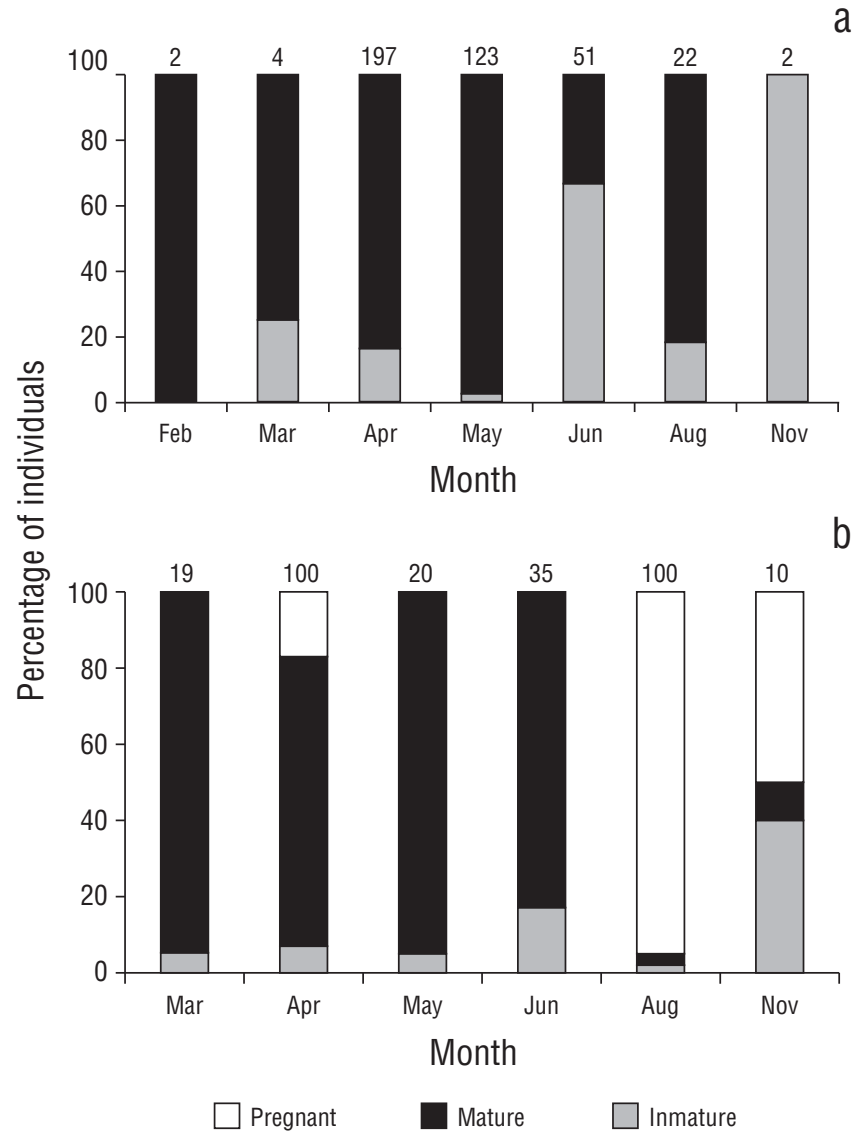

Figure 3. Seasonal variation of maturity stages for Mustelus henlei off the west coast of Baja California Sur, Mexico. (a) Maturity stages for males and (b) maturity stages for females. The numbers above the bars represent monthly sample size.

Figura 3. Variación temporal del estadio de madurez de Mustelus henlei en la costa occidental de Baja California Sur, México. (a) Estadios de madurez para machos y (b) estadios de madurez para hembras. El número arriba de la barra representa el tamaño de muestra mensual. de $670 \mathrm{~mm} \mathrm{~L}_{\mathrm{T}}(\mathrm{DE}=9.8)$ (Fig. 4), ligeramente mayor que la $\mathrm{L}_{50}$ para hembras, como se esperaba.

El aparato reproductor de las hembras estuvo conformado por un solo ovario funcional. El análisis histológico de las gónadas de hembras inmaduras mostró las primeras fases de la ovogénesis, con pequeños ovocitos (diámetro promedio $=$ $2 \mathrm{~mm}$ ) delimitados por el epitelio folicular y una capa granulosa poco diferenciada (Fig 5a). Las hembras maduras presentaron ovocitos grandes (rango de diámetro $=6-12 \mathrm{~mm}$, promedio $=$ $9 \mathrm{~mm}$ ), y el epitelio folicular se encontraba diferenciado por 4 capas (de adentro hacia afuera): zona pelúcida, capa granulosa, lámina basal y las células de la teca (Fig. 5b). El diámetro máximo de los ovocitos se registró en abril (Fig. 6).

Las hembras inmaduras presentaron glándulas oviducales de 3-8 $\mathrm{mm}$ de largo y $<10 \mathrm{~mm}$ de ancho, mientras que las hembras maduras presentaron glándulas oviducales de 10-15 mm de largo y 10-20 mm de ancho. No se encontró una relación entre el crecimiento de la glándula oviducal y la $\mathrm{L}_{\mathrm{T}}$ en cada estadio de madurez (inmaduro, maduro y preñada; $r^{2}=$ $0.27,0.07$ y 0.008 , respectivamente; $P<0.05$ ). Cuatro zonas características fueron identificadas en las secciones histológicas de la glándula oviducal: zona club, zona papilar, zona bafle y zona terminal (Hamlett et al. 2002, Hamlett 2005); estas zonas presentan un epitelio columnar simple ciliado con acinos conformados por células secretoras y células ciliadas. La presencia de semen se detectó (abril) en la zona terminal formando conglomerados en el centro de los acinos (Fig. 5c, d).

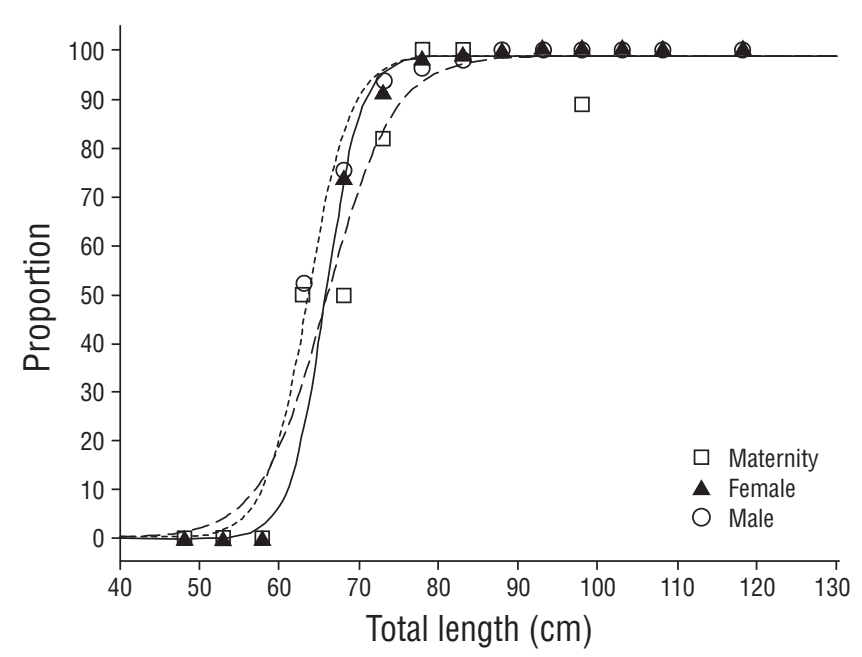

Figure 4. Length at maturity for female and male Mustelus henlei off the west coast of Baja California Sur (BCS) and length at maternity for individuals off the northwestern coast of BCS. Ogives are given for length at maternity $(---)$, males length at maturity (- - ), and female length at maturity (-).

Figura 4. Talla de madurez para hembras y machos de Mustelus henlei muestreados en la costa occidental de Baja California Sur (BCS) y talla de maternidad para individuos en la costa noroccidental de BCS. Se muestran las ojivas para la talla de maternidad (- - ) , la talla de madurez para machos (- - -) y la talla de madurez para hembras ( $\longrightarrow$ ). 

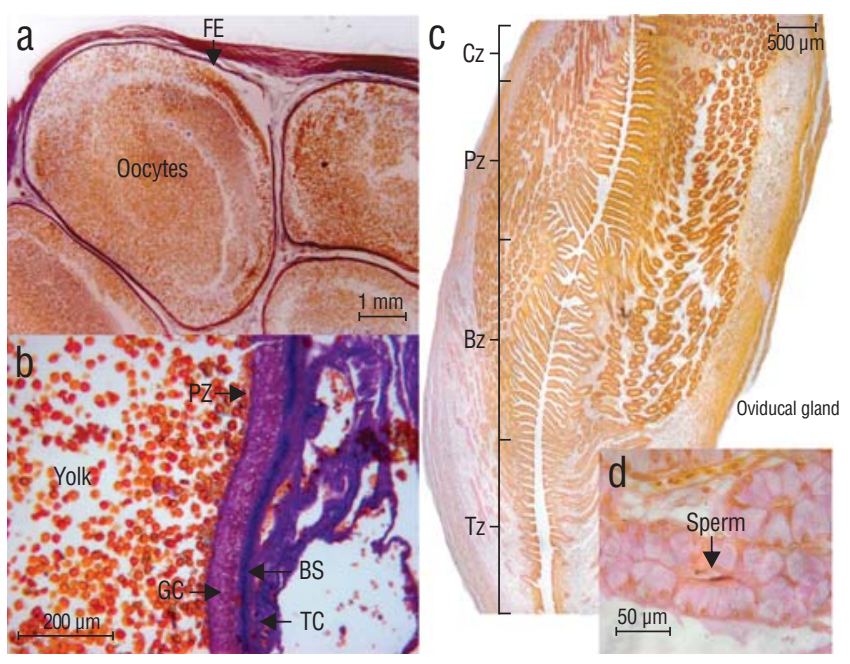

Figure 5. Histological analysis of Mustelus henlei female gonads. (a) Immature oocytes delimited by undifferentiated follicular epithelium, (b) mature oocyte showing differentiation of follicular epithelium, (c) oviducal gland showing 4 zones, and (d) acini in the terminal zone showing sperm storage. $\mathrm{FE}=$ follicular epithelium, $\mathrm{PZ}=$ pellucid zone, $\mathrm{GC}=$ granular layer, $\mathrm{BS}=$ basal surface, $\mathrm{TC}=$ theca cells, $\mathrm{Cz}=$ club zone, $\mathrm{Pz}=$ papillary zone, $\mathrm{Bz}=$ baffle zone, $\mathrm{Tz}=$ terminal zone.

Figura 5. Análisis histológico de las gónadas de hembras de Mustelus henlei. (a) Ovocitos inmaduros delimitados por un epitelio folicular indiferenciado, (b) ovocito maduro con epitelio folicular diferenciado, (c) glándula oviducal donde se muestran 4 zonas y (d) acinos de la zona terminal donde se muestra el almacenamiento de esperma. $\mathrm{FE}=$ epitelio folicular, $\mathrm{PZ}=$ zona pelúcida, $\mathrm{GC}=$ capa granulosa, $\mathrm{BS}=$ lámina basal, $\mathrm{TC}=$ células de la teca, $\mathrm{Cz}=$ zona club, $\mathrm{Pz}=$ zona papilar, $\mathrm{Bz}=$ zona bafle, $\mathrm{Tz}=$ zona terminal.

The number of embryos per female ranged between 1 and $20($ average $=9, \mathrm{SD}=5.021, n=41)$. There was a linear relation between the number of embryos and the size of females $\left(r^{2}=0.57, n=41 ; P>0.05\right)$. The embryonic sex ratio $(0.76 \mathrm{~F}: 1.00 \mathrm{M})$ was not significantly different from $1: 1\left(\chi^{2}=\right.$ $0.92, P>0.05)$, as was the case for the free-living organisms. The first embryonic stages (15-25 $\mathrm{mm} \mathrm{T}_{\mathrm{L}}$ ) were observed in females caught in the northern region in August, when 95\% of captured females were pregnant; however, maximum embryo size $\left(255 \mathrm{~mm} \mathrm{~T}_{\mathrm{L}}\right.$; average $=198.3 \mathrm{~mm} \mathrm{~T}$, $\mathrm{SD}=$ 60.3) was recorded in the southern region in April. Size at birth was estimated to be $352 \mathrm{~mm} \mathrm{~T}_{\mathrm{L}}$ and gestation period was 10-11 months, which probably started before August, when embryos were already visible in the uterus, and lasted until May-June; newborn individuals were found in August (Fig. 6).

Both testicles were functional. Testicles of immature males measured $<50 \mathrm{~mm}$ long and $10 \mathrm{~mm}$ wide on average, whereas testicles of mature males were $65 \mathrm{~mm}$ long and $14 \mathrm{~mm}$ wide on average. The first phases of spermatogenesis, including the development of the germinal epithelium in spermatic cysts and spermatogonias, were detected in

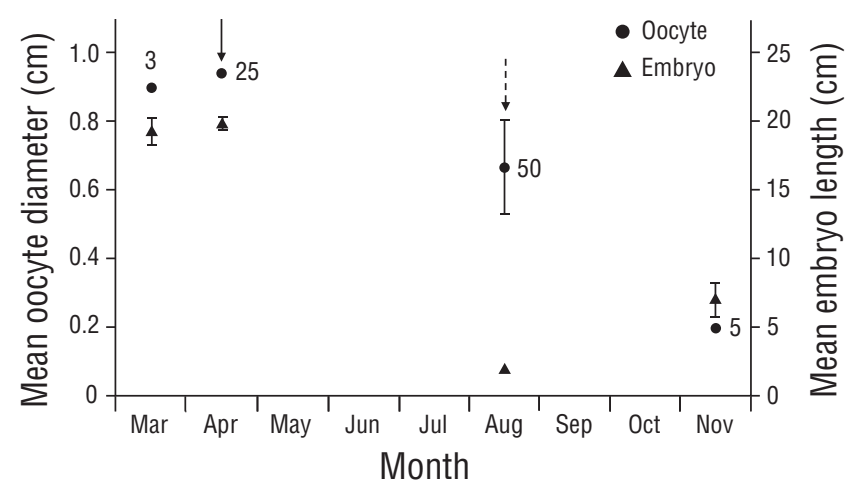

Figure 6. Seasonal variation of embryo length and oocyte diameter for Mustelus henlei females off the west coast of Baja California Sur. Values indicate mean \pm standard deviation. The numbers next to the symbols indicate the monthly sample size. The solid arrow indicates the month when embryos were largest in size and the dashed arrow the month when embryos were already visible in the uterus.

Figura 6. Variación temporal de la longitud del embrión y del diámetro del ovocito para hembras de Mustelus henlei en la costa occidental de Baja California Sur. Los valores indican el promedio \pm desviación estándar. El número cerca del símbolo indica el tamaño de muestra mensual. La flecha continua muestra el mes cuando los embriones presentaron la mayor talla y la flecha punteada el mes cuando los embriones ya eran visibles en el útero.

El número de embriones encontrados por hembra varió entre 1 y 20 (promedio $=9, \mathrm{DE}=5.021, n=41)$. Se encontró una relación lineal entre el número de embriones y la talla de las hembras $\left(r^{2}=0.57, n=41 ; P>0.05\right)$. La proporción sexual embrionaria $(0.76 \mathrm{H}: 1.00 \mathrm{M})$ no presentó diferencias significativas con respecto a la proporción 1:1 $\left(\chi^{2}=0.92, P>0.05\right)$, al igual que en el caso de los organismos de vida libre. Los primeros estadios embrionarios (15-25 $\mathrm{mm} \mathrm{L}_{\mathrm{T}}$ ) fueron observados en hembras capturadas en la zona norte en agosto, cuando el 95\% de las hembras capturadas se encontraban preñadas; sin embargo, la talla máxima de embriones $\left(255 \mathrm{~mm} \mathrm{~L}_{\mathrm{T}}\right.$, promedio $=198.3 \mathrm{~mm} \mathrm{~L}, \mathrm{DE}=$ 60.3) fue registrada en la región sur en abril. Se estimó una talla de nacimiento de $352 \mathrm{~mm} \mathrm{~L}_{\mathrm{T}}$ y un periodo de gestación de 10-11 meses, el cual probablemente inició antes de agosto, cuando los embriones ya eran visibles en el útero, y duró hasta mayo-junio; los organismos recién nacidos fueron encontrados en agosto (Fig. 6).

Ambos testículos fueron funcionales. Los testículos de los machos inmaduros midieron $<50 \mathrm{~mm}$ de largo y $10 \mathrm{~mm}$ de ancho, en promedio, mientras que los testículos de los machos maduros midieron $65 \mathrm{~mm}$ de largo y $14 \mathrm{~mm}$ de ancho, en promedio. Las primeras fases de la espermatogénesis, incluido el desarrollo del epitelio germinativo en los espermatocistos y las espermatogonias, fueron identificadas en individuos inmaduros $(\leq 510 \mathrm{~mm} \mathrm{~L}$ ), (Fig. 7a). Se encontraron espermatozoides completamente desarrollados en los testículos de machos maduros (>630 mm L $\mathrm{L}_{\mathrm{T}}$ ) (Fig. 7b), y se 
immature individuals $\left(\leq 510 \mathrm{~mm} \mathrm{~T}_{\mathrm{L}}\right)$ (Fig. 7a). Completely developed sperm cells were found in testicles of mature males (>630 $\mathrm{mm} \mathrm{T}_{\mathrm{L}}$ ) (Fig. 7b), and semen storage was found in the seminal vesicle as spermatozeugmata (Fig. 7c, d). Sperm cells in adult individuals were fully developed and grouped into organized clusters moving to the periphery of the spermatocytes associated with Sertoli cells, ready to be expelled from the testicle, through the epididymis, for storage in the seminal vesicle.

Immature males had claspers that were $<80 \mathrm{~mm}$ long and not calcified. Mature males had fully calcified claspers measuring $60-140 \mathrm{~mm}$ in length (average $=80 \mathrm{~mm}$ ). There was a significant linear relationship between the length of the testicles and $\mathrm{T}_{\mathrm{L}}\left(r^{2}=0.52, n=54 ; P>0.05\right)$; however, no significant relationship between the length of the claspers and $T_{L}$ was found with the linear model $\left(r^{2}=0.28, P<0.05\right)$ or with the nonlinear approaches (Fig. 8).

\section{Discussion}

During the present study, a new maximum size $(1,530 \mathrm{~mm}$ $\mathrm{T}_{\mathrm{L}}$ ) was recorded for $M$. henlei, considerably larger than that reported for this species in the Gulf of California (905 $\mathrm{mm} \mathrm{T}_{\mathrm{L}}$, Pérez-Jiménez and Sosa-Nishizaki 2008), off California (1,000 $\mathrm{mm} \mathrm{T}_{\mathrm{L}}$, Yudin and Cailliet 1990) and off Costa Rica (665 mm T $\mathrm{L}$, Clarke et al. 2014). Similar species in the study area, such as Mustelus californicus and Mustelus

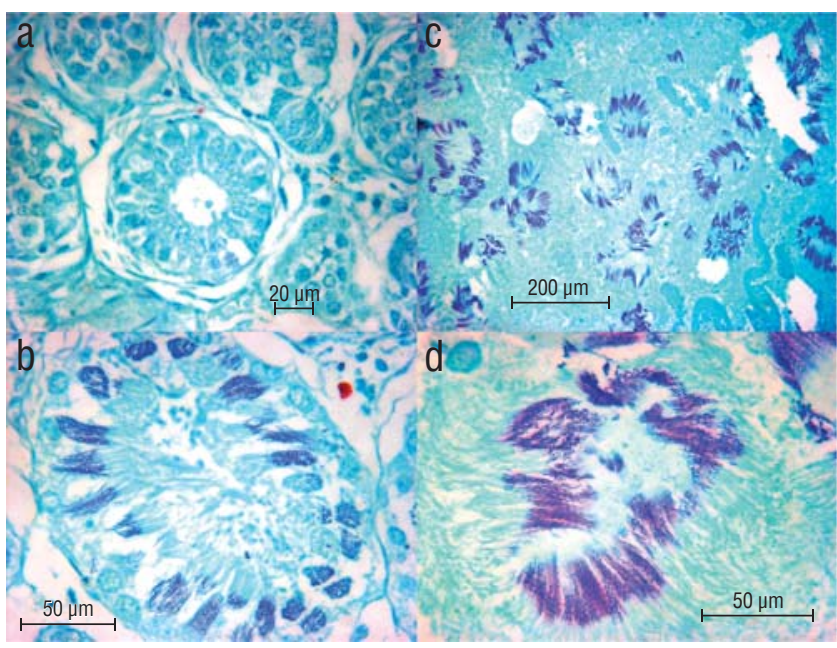

Figure 7. Histological analysis of Mustelus henlei male gonads. (a) First phase of spermatogenesis, germinal epithelium; (b) advanced stage of spermatogenesis, spermatocytes; and (c) and (d) storage of sperm in the seminal vesicle forming spermatozeugmata.

Figura 7. Análisis histológico de las gónadas de machos de Mustelus henlei. (a) Primera fase de la espermatogénesis, epitelio germinativo; (b) estado avanzado de la espermatogénesis, espermatocitos; y (c) y (d) almacenamiento de esperma en la vesícula seminal que forma el espermatozeugmata. encontró almacenamiento de semen en la vesícula seminal en forma de espermatozeugmata (Fig. 7c, d). Los espermatozoides de los organismos maduros se encontraron completamente desarrollados y agrupados en manojos compactos organizados dirigiéndose hacia la periferia del espermatocisto y asociandose con las células de Sertoli para ser expulsados del testículo, a través del epidídimo, y ser almacenados en la vesícula seminal.

Los gonopterigios de los machos inmaduros no se encontraban calcificados y midieron $<80 \mathrm{~mm}$ de largo. Los machos maduros presentaron gonopterigios completamente calcificados de 60 a $140 \mathrm{~mm}$ de largo (promedio $=80 \mathrm{~mm}$ ). Se encontró una relación lineal significativa entre el largo del testículo y la $\mathrm{L}_{\mathrm{T}}\left(r^{2}=0.52, n=54 ; P>0.05\right)$; sin embargo, no se encontró una relación significativa entre la longitud del gonopterigio y la $\mathrm{L}_{\mathrm{T}}$, ni con el modelo lineal $\left(r^{2}=0.28\right.$, $P<0.05$ ) ni con el no lineal (Fig. 8).

\section{Discusión}

En el presente estudio se registró una nueva talla máxima $\left(1,530 \mathrm{~mm} \mathrm{~L}_{\mathrm{T}}\right)$ para $M$. henlei, considerablemente mayor que lo reportado para esta especie en el golfo de California (905 mm L $\mathrm{L}_{\mathrm{T}}$ (Pérez-Jiménez y Sosa-Nishizaki 2008), frente a California $\left(1,000 \mathrm{~mm} \mathrm{~L}_{\mathrm{T}}\right.$ ) (Yudin y Cailliet 1990) y frente a Costa Rica (665 mm L $\mathrm{L}_{\mathrm{T}}$ ) (Clarke et al. 2014). Especies similares presentes en el área, como Mustelus californicus y Mustelus lunulatus, tienen características conspicuas, como dientes diferentes, y no presentan márgenes oscuros deshilachados en la aleta dorsal como M. henlei, por lo que consideramos que la probabilidad de identificación errónea de la especie es baja.

Las diferencias en las tallas en las diferentes regiones podrían atribuirse a diferencias poblacionales, pero también

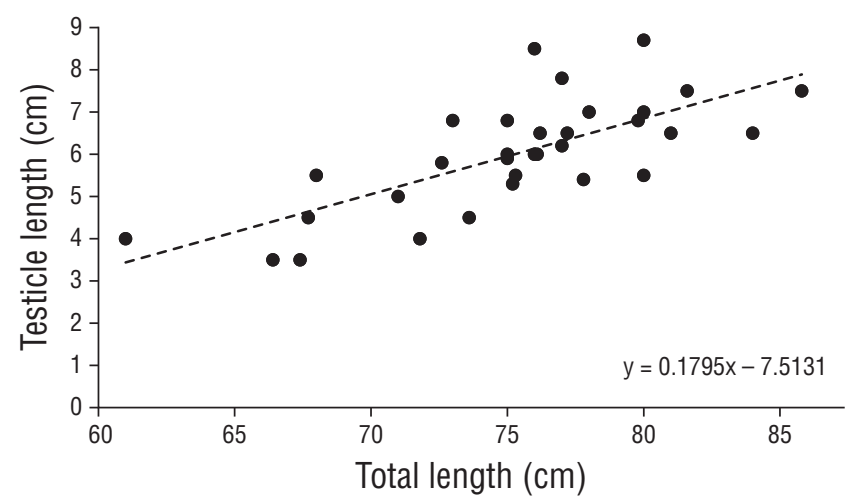

Figure 8. Relation between testicle length and total length for Mustelus henlei males sampled off the west coast of Baja California Sur.

Figura 8. Relación entre la longitud del testículo y la longitud total para los machos de Mustelus henlei muestreados en la costa occidental de Baja California Sur. 
lunulatus, have conspicuous features, like different teeth, and never dark broadly frayed margins on the dorsal fin, like $M$. henlei, and we thus consider that the probability of species misidentification is low.

The difference in specimen sizes among different regions could be attributed to population differences, but it could also be attributed to the selectivity of fishing gear and to the fishing zone. Mustelus henlei is caught off the western coast of BCS (present study) using gillnets with a mesh size of $150 \mathrm{~mm}$ at a depth of approximately $100 \mathrm{~m}$, and in the Gulf of California it is mainly caught with bottom-set longlines, trawl nets, and gillnets with smaller mesh size $(100 \mathrm{~mm})$ at depths between 80 and $100 \mathrm{~m}$ (Pérez-Jiménez and Sosa-Nishizaki 2008). Off California M. henlei is caught with gillnets, trammel nets, otter trawls, and hooks, but only in shallow waters not exceeding $38.1 \mathrm{~m}$ (Yudin and Cailliet 1990).

Female $M$. henlei in the study area showed larger sizes than males, similar to that reported for this species in the Gulf of California (Pérez-Jiménez and Sosa-Nishizaki 2008), off California (Yudin and Cailliet 1990), and off Costa Rica (Clarke et al. 2014) and for other mustelids, such as M. antarcticus (Walker 2007), Mustelus canis (Conrath and Musick 2002), Mustelus lenticulatus (Francis and Mace 1980), and M. manazo (Tanaka and Mizue 1979). This difference in size could be associated with a reproductive strategy, as females need a bigger size to keep embryos inside their bodies (Walmsley-Hart et al. 1999).

Seasonal variation in the abundance of $M$. henlei in landings along the western coast of BCS could be due to migratory behavior associated with reproductive or dietary factors (Campos et al. 2009). Migratory behavior associated with species reproduction has been suggested to ensure that embryos are exposed to favorable temperatures during their development (Francis 1988). In addition, the search for food to increase energy reserves for the nutrition of embryos during their development has been stated as an explanation for $M$. lenticulatus migration (Francis and Mace 1980, Francis 1988). The western coast of BCS is characterized by high productivity rates in different regions and seasons. Since prey are found in high-productivity areas, several elasmobranchs migrate along the peninsula following their prey (Block et al. 2011). However, the lack of telemetry studies limits knowledge on the causes for M. henlei migration.

In the present study we estimated $\mathrm{L}_{50}$ for $M$. henlei off the west coast of BCS for the first time using a logistic model. Maturity stages were determined and validated through histological analysis. Likewise, $\mathrm{L}_{\mathrm{m} 50}$ was estimated for the first time for this species. Estimating $\mathrm{L}_{\mathrm{m} 50}$ allowed us to validate the annual reproductive cycle of $M$. henlei in Bahía Tortugas. Though we could not validate this for the southern and central portions of the west coast of BCS, the presence of fully developed embryos and large oocytes (up to $12 \mathrm{~mm}$ ) indicate that the reproductive cycle might not be different podrían atribuirse a la selectividad del arte de pesca empleado y a la zona de captura. Mustelus henlei es capturada en la costa occidental de BCS (presente estudio) mediante redes de enmalle con luz de malla de $150 \mathrm{~mm}$ colocadas a profundidades de hasta $100 \mathrm{~m}$, mientras que en el norte del golfo de California la captura se realiza con palangres de fondo, redes de arrastre y redes de enmalle con una luz de malla más pequeña $(100 \mathrm{~mm})$ a profundidades de entre 80 y $100 \mathrm{~m}$ (Pérez-Jiménez y Sosa-Nishizaki 2008). Frente a California, $M$. henlei es capturada por medio de redes de enmalle, redes de trasmallo, redes de arrastre y anzuelos, pero a profundidades no mayores que $38.1 \mathrm{~m}$ (Yudin y Cailliet 1990).

Las hembras de $M$. henlei presentaron tallas más grandes que los machos en el área de estudio, similar a lo reportado para la especie en el golfo de California (Pérez-Jiménez y Sosa-Nishizaki 2008), frente a California (Yudin y Cailliet 1990) y frente a Costa Rica (Clarke et al. 2014) y para otros mustélidos como M. antarcticus (Walker 2007), Mustelus canis (Conrath y Musick 2002), Mustelus lenticulatus (Francis y Mace 1980) y M. manazo (Tanaka y Mizue 1979). Estas diferencias en tamaño podrían estar relacionadas a la estrategia reproductiva, ya que las hembras necesitan de un mayor tamaño para mantener a los embriones dentro de su cuerpo (Walmsley-Hart et al. 1999).

La estacionalidad en la variación de la abundancia de M. henlei en las capturas a lo largo de la costa occidental de BCS pudiera deberse a un comportamiento migratorio asociado a factores reproductivos o de alimentación (Campos et al. 2009). Se ha sugerido que el comportamiento migratorio asociado a la reproducción asegura que los embriones estén expuestos a temperaturas favorables durante su desarrollo (Francis 1988). Asimismo, la búsqueda de alimento para aumentar las reservas de energía para la nutrición de los embriones durante su desarrollo ha sido sugerida como una explicación para la migración de $M$. lenticulatus (Francis y Mace 1980, Francis 1988). La costa occidental de BCS se caracteriza por las altas tasas de productividad en diferentes regiones y temporadas. Esto propicia que diferentes especies de elasmobranquios puedan realizar migraciones a lo largo de la península en busca de sus presas (Block et al. 2011). Sin embargo la falta de estudios de telemetría limita el conocimiento de las causas de migración para $M$. henlei.

En el presente estudio se estimó, por primera vez, la $\mathrm{L}_{50}$ para $M$. henlei frente a la costa occidental de BCS con base en un modelo logístico. Además, los estadios de madurez fueron determinados y validados mediante el análisis histológico. Por otra parte, se estimó por primera vez la $\mathrm{L}_{\mathrm{m} 50}$ para la especie. La estimación de $\mathrm{L}_{\mathrm{m} 50}$ permitió validar que $M$. henlei presenta un ciclo reproductivo anual en bahía Tortugas. Aunque esto no pudo ser validado para el sur y centro de la costa occidental de BCS, la presencia de embriones completamente desarrollados y de ovocitos grandes (hasta $12 \mathrm{~mm}$ ) indica que el ciclo reproductivo podría no ser diferente a lo encontrado en bahía Tortugas. Se recomienda muestrear hembras preñadas en estas áreas durante todo el año. 
from what was found in Bahía Tortugas. We recommend sampling pregnant females in these areas all year around.

Previous studies on elasmobranch reproduction determined maturity stages according to the macroscopic examination of reproductive organs and the external characteristics of organisms (Yudin and Cailliet 1990, Pérez-Jiménez and Sosa-Nishizaki 2008, Clarke et al. 2014). In the present study the histological analysis was used for the first time as a complementary tool to increase knowledge on the reproduction of $M$. henlei and to validate macroscopic observations. Both males and females off the west coast of BCS reach maturity at a larger size than do the stocks from the Gulf of California (Pérez-Jiménez and Sosa-Nishizaki 2008), California (Yudin and Cailliet 1990), and Costa Rica (Clarke et al. 2014) (Table 2). However, this comparison should be taken with caution, as different criteria were used to determine maturity. Yudin and Cailliet (1990) used the relationship between clasper length and $T_{L}$ for males and the presence of embryos and oocytes $>10 \mathrm{~mm}$ in diameter for females. Pérez-Jiménez and Sosa-Nishizaki (2008), on the other hand, used the length and condition of claspers (free rotation) for males and oocytes diameter, size of oviducal gland, and uterus width $(>8.1 \mathrm{~mm}$, $>11 \mathrm{~mm}$, and $>12 \mathrm{~mm}$, respectively) for females. Clarke et al. (2014) used the length and condition of claspers (calcification) for males and the presence of oocytes in the ovary and the development of the oviducal gland for females. In the present study, we used the histological analysis of testicles and the length and condition of claspers (free rotation and complete calcification) for males and the presence of embryos, presence of oocytes $>6 \mathrm{~mm}$ in diameter, and histological analysis of ovaries and oviducal glands for females.

Differences in fecundity were also observed in comparison with the California, Gulf of California, and Costa Rica stocks (Yudin and Cailliet 1990, Pérez-Jiménez and Sosa-Nishizaki 2008, Clarke et al. 2014) (Table 1). Differences in reproductive parameters (e.g., length at maturity and fecundity) can be attributed to variations in water temperature at each study area. In the northern Gulf of California region,
Los estudios previos sobre la reproducción de elasmobranquios se basaron en estadios de madurez determinados por el análisis macroscópico de los órganos reproductores y en las características externas de los organismos (Yudin y Cailliet 1990, Pérez-Jiménez and Sosa-Nishizaki 2008, Clarke et al. 2014). En el presente estudio el análisis histológico fue realizado por primera vez como una herramienta complementaria para aumentar el conocimiento de la reproducción de la especie y validar las observaciones macroscópicas. Se observó que tanto machos como hembras de la costa occidental de BCS alcanzan la madurez a mayores tallas que las poblaciones del golfo de California (Pérez-Jiménez y Sosa-Nishizaki 2008), California (Yudin y Cailliet 1990) y Costa Rica (Clarke et al. al 2014) (Tabla 2). Sin embargo, esta comparación debe tomarse con precaución, ya que los estudios anteriores utilizaron diferentes criterios para determinar la madurez. Yudin y Cailliet (1990) utilizaron la relación entre la longitud de los gonopterigios y $\mathrm{L}_{\mathrm{T}}$ para machos y la presencia de embriones y ovocitos con diámetro $>10 \mathrm{~mm}$ para las hembras. En cambio, Pérez-Jiménez y Sosa-Nishizaki (2008) utilizaron la longitud y condición de los gonopterigios (libre rotación) para los machos y el diámetro de los ovocitos, el tamaño de la glándula oviducal y el ancho del útero $(>8.1 \mathrm{~mm},>11 \mathrm{~mm}$ y $>12 \mathrm{~mm}$, respectivamente) para las hembras. Clarke et al. (2014) utilizaron la longitud y condición de los gonopterigios (calcificación) para los machos y la presencia de ovocitos en el ovario y el desarrollo de la glándula oviducal para las hembras. En el presente estudio se utilizaron los análisis histológicos del testículo y la longitud y condición de los gonopterigios (libre rotación y calcificación completa) para los machos y la presencia de embriones, la presencia de ovocitos con diámetro $>6 \mathrm{~mm}$ y los análisis histológicos del ovario y de la glándula oviducal para las hembras.

Se encontraron diferencias en la fecundidad en comparación con las poblaciones de California, el golfo de California y Costa Rica (Yudin y Cailliet 1990, Pérez-Jiménez y Sosa-Nishizaki 2008, Clarke et al. 2014) (Tabla 1). Las

Table 2. Comparison of reproductive parameters for Mustelus henlei populations in the eastern Pacific. $T_{L}=$ total length.

Tabla 2. Comparación de los parámetros reproductivos de poblaciones de Mustelus henlei en el Pacífico oriental. $\mathrm{T}_{\mathrm{L}}=$ longitud total.

\begin{tabular}{|c|c|c|c|c|}
\hline Reproductive parameter & $\begin{array}{c}\text { California } \\
\text { (Yudin and } \\
\text { Cailliet 1990) }\end{array}$ & $\begin{array}{c}\text { Gulf of California } \\
\text { (Pérez-Jiménez and } \\
\text { Sosa-Nishizaki 2008) }\end{array}$ & $\begin{array}{c}\text { Costa Rica } \\
\text { (Clarke et al. 2014) }\end{array}$ & $\begin{array}{l}\text { West coast of Baja } \\
\text { California Sur } \\
\text { (present study) }\end{array}$ \\
\hline Length at maturity for males $\left(\mathrm{mm} \mathrm{T}_{\mathrm{L}}\right)$ & $510-630$ & $550-560$ & 372 & 635 \\
\hline Length at maturity for females ( $\mathrm{mm} \mathrm{T}_{\mathrm{L}}$ ) & $520-660$ & $570-660$ & 397 & 658 \\
\hline Fecundity & $1-10$ & $1-21$ & $1-12$ & $4-20$ \\
\hline Pregnancy period (months) & $10-11$ & 10 & - & $10-11$ \\
\hline Parturition period & - & January-April & - & May-June \\
\hline
\end{tabular}


sea surface temperature varied from 18 to $28{ }^{\circ} \mathrm{C}$ (Escalante et al. 2013) and off the California coast it varied from 18 to $20{ }^{\circ} \mathrm{C}$ (Nezlin et al. 2004); these temperatures are considerably different from sea surface temperature off the west coast of BCS $\left(12-30^{\circ} \mathrm{C}\right)$ (Sicard-González et al. 2012).

The number of embryos that a female can produce is highly variable among elasmobranchs. The relationship between the number of embryos and $\mathrm{T}_{\mathrm{L}}$, such as that found for $M$. henlei in the present study, has been reported for some species, for example M. antarcticus (Walker 2007), M. lunulatus, and M. californicus (Pérez-Jiménez and Sosa-Nishizaki 2010). This relationship implies that larger females can have larger litter sizes (Clarke et al. 2014), which could explain a relation between the capacity of the population to increase in size and the number of larger females.

The breeding period in the study area was estimated to occur from May to June, according to the April records of embryos with sizes close to the reported size at birth $\left(28 \mathrm{~mm} \mathrm{~T} \mathrm{~T}_{\mathrm{L}}\right.$ ) for the northern Gulf of California region, though breeding in the northern gulf region had been estimated to occur from January to April (Pérez-Jiménez and Sosa-Nishizaki 2008). This difference can be attributed to environmental conditions as well. The association between breeding period and temperature variation has also been reported for M. antarcticus (Walker 2007) and M. manazo (Yamaguchi et al. 2000).

Many mustelids have annual reproductive cycles, and such is the case for M. antarcticus off the southwestern coast of Australia (Walker 2007), M. lenticulatus off New Zealand (Francis and Mace 1980), M. canis in the northwestern Atlantic Ocean (Conrath and Musick 2002), and M. manazo off Japan (Yamaguchi et al. 2000). Considering that maximum follicle size and fully developed embryos occurred simultaneously in April, M. henlei could too show a continuous annual reproductive cycle off the west coast of BCS. However, some populations have been shown to present different periodicity in relation to environmental conditions (Walker 2007).

The reproductive system of elasmobranchs has undergone evolutionary modifications and/or adaptations (Hamlett 2005). Some species, like Squalus acanthias, Squalus brevirostris, Notorynchus masculatus, and Carcharhinus anguineus, have 2 functional ovaries (Lutton et al. 2005). Other species, like $M$. henlei, have only 1 functional ovary, where oogenesis and the synthesis and secretion of hormones occur (Lutton et al. 2005). This condition has also been observed in other Mustelus species (Carrier et al. 2004), such as M. antarcticus (Walker 2007), M. lunulatus, and M. californicus (pers. obs.).

Oogenesis in elasmobranchs has been recorded to occur at an early age and oogonia are only observed during embryonic development (McMillan 2007, Serra-Pereira et al. 2011), so early stages of oogenesis can occur in immature females (Serra-Pereira et al. 2011). This was corroborated with the histological images of the first stages of development of the previtelogenic follicles found in immature $M$. henlei females showing early oogenesis. diferencias en los parámetros reproductivos (e.g., talla de madurez y fecundidad) podrían ser atribuidas a las variaciones en la temperatura del agua de cada zona de estudio. En la zona norte del golfo de California, la temperatura superficial del mar varió de 18 a $28^{\circ} \mathrm{C}$ (Escalante et al. 2013) y en las costas de California la temperatura varió de 18 a $20^{\circ} \mathrm{C}$ (Nezlin et al. 2004), temperaturas que son considerablemente diferentes a las que se han registrado para la costa occidental de BCS $\left(12-30^{\circ} \mathrm{C}\right)$ (Sicard-González et al. 2012).

El número de embriones que puede producir una hembra es ampliamente variable entre los elasmobranquios. La relación entre el número de embriones y la $\mathrm{L}_{\mathrm{T}}$, como lo encontrado para $M$. henlei en el presente estudio, ha sido reportada para otras especies, por ejemplo, M. antarcticus (Walker 2007), M. lunulatus y M. californicus (Perez-Jimenez y Sosa-Nishizaki 2010). Esta relación implica que las hembras más grandes pueden tener un tamaño de camada más grande (Clarke et al. 2014), lo cual podría relacionar la capacidad de la población para aumentar en tamaño con el número de hembras más grandes presentes.

Se estimó que el periodo de nacimiento para el área estudiada es de mayo a junio, con base en el registro de embriones de abril con talla cercana a la talla de nacimiento reportada $\left(28 \mathrm{~mm} \mathrm{~L}_{\mathrm{T}}\right.$ ) para el norte del golfo de California, aunque para el norte del golfo se había estimado que el periodo de nacimiento era de enero a abril (Pérez-Jiménez y Sosa-Nishizaki 2008). Esta diferencia podría atribuirse a las condiciones ambientales. La asociación entre el periodo de alumbramiento y la variación en la temperatura también ha sido reportada para M. antarcticus (Walker 2007) y M. manazo (Yamaguchi et al. 2000).

Varias especies de mustélidos presentan un ciclo reproductivo anual, como sucede con $M$. antarcticus en la costa suroccidental de Australia (Walker 2007), M. lenticulatus frente a en Nueva Zelanda (Francis y Mace 1980), M. canis en el noroeste del océano Atlántico (Conrath y Musick 2002) y M. manazo frente a Japón (Yamaguchi et al. 2000). Considerando que el máximo tamaño de los folículos y el completo desarrollo embrionario ocurrieron simultáneamente en abril, es posible proponer que $M$. henlei presenta un ciclo reproductivo anual continuo en la costa occidental de BCS. Sin embargo, se ha demostrado que algunas poblaciones pueden presentar diferentes periodicidades, en relación con las condiciones ambientales (Walker 2007).

El aparato reproductor de los elasmobranquios presenta modificaciones y/o adaptaciones evolutivas (Hamlett 2005). Algunas especies, como Squalus acanthias, Squalus brevirostris, Notorynchus masculatus y Carcharhinus anguineus, tienen 2 ovarios funcionales (Lutton et al. 2005). Otras especies, como $M$. henlei, presentan solo 1 ovario funcional, donde sucede el proceso de ovogénesis y la síntesis y secreción de hormonas (Lutton et al. 2005). Esta condición se presenta también en otras especies del género Mustelus (Carrier et al. 2004), como M. antarcticus (Walker 2007), M. lunulatus y M. californicus (obs. pers.). 
In males, testicle development is marked by cell differentiation and growth, which are associated with changes in the diameter and composition of spermatic cysts (Maruska et al. 1996). Immature males showed the first stages of spermatogenesis: germinal epithelium, cells not well-organized, and/or primary spermatogonia. Primary spermatogonia were in active multiplication by mitosis and were aligned in the basal membrane, showing heterochromatin granules in the nucleosome and cytoplasm with limited presence of organelles (where mitochondria predominate). The nuclei of Sertoli cells were aligned toward the lumen of spermatic cysts.

In the present study we confirmed that semen storage occurs in the oviducal glands of M. henlei. This phenomenon has been reported for other mustelids, such as M. antarcticus, which has a short storage period between postpartum and the following ovulation (Walker 2007). Other sharks in which semen storage has been known to occur are Iago omanensis (Hamlett et al. 2002), Prionace glauca, Lamna nasus, Carcharhinus obscurus, Carcharhinus plumbeus, Galeocerdo cuvier, Sphyrna lewini, and Sphyrna tiburo (Pratt 1993).

Fertilization in elasmobranchs is internal and occurs in the oviducal gland, where semen can be stored for days, months, or years in the terminal zone as dense packages or in a loosely packed form depending on the species (Hamlett et al. 2005). This allows females to ensure fertilization and control the moment of fecundation while considering the optimum environmental conditions for the survival of the offspring (Maruzka et al. 1996). This strategy is used mainly by highly migratory species or those that present strong segregation by sex (Pratt 1993).

Sperm cells were found in acini on the periphery of the terminal zone of the oviducal gland and were associated with the mucous membrane of ciliated cells. Pratt (1993) determined that the storage period depends on the position of sperm inside the oviducal glands. The activity of acini in the terminal zone is associated with the storage, transport, and preservation (nutrition) of sperm cells inside the oviducal gland until the moment of fertilization (Hamlett et al. 2002). Because sperm were loosely packed in tubules, with heads away from the lumen, we can state that the period of semen storage in $M$. henlei is short.

Semen storage in males occurs in the seminal vesicles (Pratt and Tanaka 1994). In M. henlei storage of sperm cells occurred as spermatozeugmata, which are organized masses of free semen that are attached to a cohesive matrix that is ovoid or spherical in shape (Pratt and Tanaka 1994). This type of aggregation has been reported for other shark species too, such as S. lewini, P. glauca, and Carcharhinus falciformis (Pratt and Tanaka 1994). Semen packaging could be a highly efficient strategy to transfer semen to females, with lower losses during copulation compared with semen in liquid form (Matthews 1950).

The reproductive parameters estimated for $M$. henlei in the present study (relatively high fecundity, annual reproductive cycle, and early maturation) allow us to suggest that, like
Se ha registrado que la ovogénesis en elasmobranquios ocurre a una edad temprana y las ovogonias sólo se observan durante el desarrollo embrionario (McMillan 2007, Serra-Pereira et al. 2011), de modo que las hembras inmaduras pueden presentar algún estado inicial de ovogénesis (Serra-Pereira et al. 2011). Esto fue corroborado por las imágenes histológicas de las primeras etapas de desarrollo de los folículos previtelogénicos encontradas en hembras inmaduras de $M$. henlei que presentaron ovogénesis temprana.

En los machos, el desarrollo de los testículos está caracterizado por la diferenciación y maduración celular, asociadas con cambios en la composición y diámetro de los espermatocistos (Maruska et al. 1996). Los machos inmaduros presentaron las primeras fases de la espermatogénesis: epitelio germinativo, células poco organizadas y/o espermatogonias primarias. Las espermatogonias primarias se encontraron en multiplicación activa por mitosis y alineadas en la membrana basal, y presentaron gránulos de heterocromatina en el nucleosoma y un citoplasma con reducida presencia de organelos (en donde predominan las mitocondrias). Los núcleos de las células de Sertoli se encontraron alineados hacia el lumen del espermatocisto.

En el presente estudio se confirmó que el almacenamiento de semen ocurre en las glándulas oviductales de M. henlei. Este fenómeno ha sido reportado para otras especies de mustélidos, como M. antarcticus, que presenta un periodo corto de almacenamiento entre el final del periodo de parto y el siguiente periodo de ovulación (Walker 2007). Otros tiburones en los cuales se ha reportado almacenamiento de semen son Iago omanensis (Hamlett et al. 2002), Prionace glauca, Lamna nasus, Carcharhinus obscurus, Carcharhinus plumbeus, Galeocerdo cuvier, Sphyrna lewini y Sphyrna tiburo (Pratt 1993).

La fertilización en los elasmobranquios es interna y sucede en la glándula oviducal, donde el semen puede ser almacenado por días, meses o años en la zona terminal, en paquetes densos o de forma libre dependiendo de la especie (Hamlett et al. 2005). Esto permite que la hembra pueda garantizar la fertilización y controlar el momento de la fecundación considerando las condiciones ambientales óptimas para la supervivencia de las crías (Maruzka et al. 1996). Esta estrategia es utilizada principalmente por especies altamente migratorias o que presenten una marcada segregación por sexo (Pratt 1993).

Los espermatozoides fueron localizados en los acinos de la periferia de la zona terminal de la glándula oviducal, y estuvieron asociados a la membrana mucosa de las células ciliadas. Pratt (1993) determinó que el tiempo de almacenamiento depende de la posición del esperma en la glándula oviducal. La actividad de los acinos en la zona terminal está relacionada con el almacenamiento, transporte y mantenimiento (nutrición) de los espermatozoides dentro de la glándula oviducal hasta el momento de la fertilización (Hamlett et al. 2002). Debido a que los espermatozoides estaban de forma libre en los túbulos con la cabeza lejos del lumen, podemos 
other mustelids, this species has relatively high biological productivity among elasmobranchs (Walker 2005b). We also defined differences in some reproductive parameters between $M$. henlei and other stocks in Mexican and United States waters, highlighting the need for regionalizing protective or fishing management measures for this species by taking into account the reproductive aspects of each stock.

The restrictions implemented in 2012 to the Mexican elasmobranch fishery, including the yearly closed fishing season from 1 May to 31 July (DOF 2007), apparently protect $M$. henlei off the west coast of BCS during the reproductive period. However, the present study provides new information on the reproductive biology of $M$. henlei for different regions along the west coast of BCS, which could contribute to improve fishery management measures for the sustainable use of this resource. Our results show that the northwestern coast of BCS is an important reproduction area, where up to $95 \%$ of $M$. henlei catches in August are pregnant females; therefore, an extension of the closed fishing season can be suggested for this area. On the other hand, on the southwestern coast of BCS, females with embryos nearly ready for birth can be found in April, and it would be important to consider this for the protection of this species as well. These results show the importance of the regionalization of conservation and management measures based on our new findings on the reproductive biology of $M$. henlei, considering the spatial and temporal distribution of this species.

\section{ACKNOWLEDGMENTS}

This study was financed through the sharks and rays project from CICIMAR-IPN. FGM thanks IPN (Comisión de Operación y Fomento de Actividades Académicas, Estímulos al Desempeño de los Investigadores) for the granted fellowships. We thank the Morphophysiology laboratory at CICIMAR-IPN, the fishermen of the Aquaculture of the Pacific S.A. of C.V. cooperative at Bahía Tortugas and the fishermen at Punta Lobos. We also thank the anonymous reviewers for the useful comments that improved the manuscript and Warren Hair for reviewing the English.

\section{REFERENCES}

Andreuccetti P, Iodice M, Prisco M, Gualtieri R. 1999. Intercellular bridges between granulosa cells and the oocyte in the elasmobranch Raya asterias. Anat. Rec. 255(2): 180-187. http://dx.doi.org/10.1002/(SICI)1097-0185(19990601)255:2<180::AID-AR8>3.0.CO;2-S

Block BA, Jonsen ID, Jorgensen SJ, Winship AJ, Shaffer SA, Bograd SJ, Hazen EL, Foley DG, Breed GA, Harrison AL et al. 2011. Tracking apex marine predator movements in a dynamic ocean. Nature 475(7354): 86-90. http://dx.doi.org/10.1038/nature10082

Campos BR, Fish MA, Jones G, Riley RW, Allen PJ, Klimley PA. 2009. Movements of brown smoothhounds, Mustelus henlei, in Tomales Bay, California. Environ. Biol. Fish. 85(1): 3-13. http://dx.doi.org/10.1007/s10641-009-9462-y inferir que $M$. henlei presenta almacenamiento de semen de corto plazo.

El almacenamiento de semen en los machos ocurre en la vesícula seminal (Pratt y Tanaka 1994). En M. henlei el almacenamiento de esperma se da en forma de espermatozeugmata, que consiste en masas organizadas de esperma libre unidas con una matriz cohesiva en forma ovoide o esférica (Pratt y Tanaka 1994). Este tipo de agregación ya ha sido reportado para otras especies de tiburones, como S. lewini, P. glauca y Carcharhinus falciformis (Pratt y Tanaka 1994). El empaquetamiento del semen podría ser una estrategia de mayor eficiencia para la transferencia de semen a las hembras, con menor perdida durante el proceso de cópula en comparación con el semen completamente fluido (Matthews 1950).

Los parámetros reproductivos estimados para $M$. henlei en el presente estudio (fecundidad relativamente alta, ciclo reproductivo anual y maduración temprana) nos permiten proponer que la especie, como otros mustélidos, tiene una productividad biológica relativamente alta entre los elasmobranquios (Walker 2005b). Asimismo, fue posible establecer diferencias entre algunos parámetros reproductivos de $M$. henlei y otras poblaciones presentes en aguas mexicanas y de Estados Unidos, lo cual resalta la necesidad de regionalizar las medidas de protección o manejo pesquero para la especie con base en los aspectos reproductivos que presenta cada población.

Las restricciones implementadas en 2012 para la pesquería mexicana de elasmobranquios, incluida la temporada de no pesca del 1 de mayo al 31 de julio de cada año (DOF 2007), parecen proteger el periodo reproductivo de $M$. henlei en la costa occidental de BCS. Sin embargo, el presente estudio proporciona nueva información sobre la biología reproductiva de $M$. henlei para diferentes regiones de la costa occidental de BCS, lo que podría contribuir a mejorar las medidas de manejo pesquero para lograr el uso sostenible de esta especie. Nuestros resultados mostraron que la costa noroccidental de BCS es una área de reproducción importante, donde hasta el $95 \%$ de las capturas de $M$. henlei en agosto son hembras preñadas, por lo que se podría proponer una extensión de la temporada de veda para esta área. Por otra parte, en la costa suroccidental de BCS es posible encontrar hembras con embriones casi listos para nacer durante el mes de abril, lo cual también sería importante considerar para la protección de esta especie. Estos resultados muestran la importancia de la regionalización de las medidas de conservación y manejo basadas en esta nueva información de la biología reproductiva de $M$. henlei, considerando tanto la distribución espacial como la distribución temporal de la especie.

\section{Agradecimientos}

Este estudio fue financiado a través del proyecto de tiburones y rayas del CICIMAR-IPN. FGM agradece al IPN 
Carrier JC, Pratt HL, Castro JI. 2004. Reproductive Biology of Elasmobranchs. In: Carrier JC, Musick JA, Heithaus MR (eds.), Biology of Sharks and their Relatives. CRC Press. LLC. Boca Raton, FL, pp. 269-286. https://doi.org/10.1201/9780203491317.ch10

Clarke TM, Espinoza M, Wehrtmann IS. 2014. Reproductive ecology of demersal elasmobranchs from a data-deficient fishery, Pacific of Costa Rica, Central America. Fish. Res. 157: 96-105. http://dx.doi.org/10.1016/j.fishres.2014.04.003

Compagno LJ, Dando M, Fowler S. 2005. Sharks of the world. Harper Collins, London, $368 \mathrm{pp}$.

Conrath CL, Musick, JA. 2002. Reproductive biology of the smooth dogfish, Mustelus canis, in the northwest Atlantic Ocean. Environ. Biol. Fishes 64(4): 367-377. http://dx.doi.org/10.1023/A:1016117415855

[DOF] Diario Oficial de la Federación. 2007 Feb 14. Norma Oficial Mexicana NOM-029-PESC-2006, Pesca responsable de tiburones y rayas. Especificaciones para su aprovechamiento. Secretaría de Agricultura, Ganadería, Desarrollo Rural, Pesca y Alimentación, Mexico City.

Escalante F, Valdez-Holguín JE, Álvarez-Borrego S, Lara-Lara JR. 2013. Temporal and spatial variation of sea surface temperature, chlorophyll $a$, and primary productivity in the Gulf of California = Variación temporal y espacial de temperatura superficial del mar, clorofila $a$ y productividad primaria en el golfo de Calfornia. Cienc. Mar. 39(2): 203215. http://dx.doi.org/10.7773/cm.v39i2.2233

Francis MP. 1988. Movement patterns of rig (Mustelus lenticulatus) tagged in southern New Zealand. N. Z. J. Mar. Freshwater Res. 22(2): 259-272.

http://dx.doi.org/10.1080/00288330.1988.9516298

Francis MP, Mace JT. 1980. Reproductive biology of Mustelus lenticulatus from Kaikoura and Nelson. N. Z. J. Mar. Freshwater Res. 14(3): 303-311. http://dx.doi.org/10.1080/00288330.1980.9515873

Furlong-Estrada E, Galván-Magaña F, Tovar-Ávila J. 2017. Use of the productivity and susceptibility analysis and a rapid management-risk assessment to evaluate the vulnerability of sharks caught off the west coast of Baja California Sur, México. Fish. Res. 194: 197-208. http://dx.doi.org/10.1016/j.fishres.2017.06.008

Hamlett WC. 2005. Reproductive biology and phylogeny of Chondricthyes. Sharks, Batoids and Chimeras. Sience Publishers, USA, 562 pp.

Hamlett WC, Fishelson L, Baranes A, Hysell AK, Server DM. 2002. Ultrastructural analysis of sperm storage and morphology of the oviducal gland in the Oman shark, Iago omanensis (Triakidae). Mar. Freshwat. Res. 53(2): 601-613. http://dx.doi.org/10.1071/MF01080

Hamlett WC, Kormanik G, Storrie MT, Stevens B, Walker TI. 2005. Chondrichthyan parity, lecithotrophy and matrotrophy. In: Hamlett WC (ed.). Reproductive Biology and Phylogeny of Chondrichthyes: Sharks, Batoids and Chimaeras. Science Publishers, Enfield (NH), pp. 395-434.

Humason GL. 1979. Animal Tissue Techniques (4th ed.). Freeman and Company, USA, $661 \mathrm{pp}$.

Lutton B, George St, Murrin J, Fileti CL, Callard I. 2005. The elasmobranch ovary. In: Hamlett WC (ed.), Reproductive Biology and Phylogeny of Chondrichthyes: Sharks, Batoids and Chimaeras. Science Publishers, Plymouth (UK), pp. 237-282.

McMillan DB. 2007. Ovarian follicles. In: McMilan DB (ed.), Fish histology: female reproductive system. Springer-Verlag, New York, pp. 67-208.
(Comisión de Operación y Fomento de Actividades Académicas, Estímulos al Desempeño de los Investigadores) las becas otorgadas. Agradecemos al laboratorio de Morfofisiología del CICIMAR-IPN, a los pescadores de la cooperativa Acuicultura del Pacífico S.A. de C.V. de bahía Tortugas y a los pescadores de punta Lobos. También agradecemos a los revisores anónimos los comentarios útiles que mejoraron el manuscrito y a Warren Hair la revisión del inglés.

Maruska KP, Cowie EG, Tricas TC. 1996. Periodic gonadal activity and protracted mating in elasmobranch fishes. J. Exp. Zool. 276(3): 219-232.

http://dx.doi.org/10.1002/(SICI)1097-010X(19961015)276:3<219::AID-JEZ6>3.0.CO;2-Q

Matthews LH. 1950. Reproduction in the basking shark, Cetorhinus maximus (Gunner). Philos. Trans. Zool. Soc. Lond. 234: 247316.

http://dx.doi.org/10.1098/rstb.1950.0003

Mollet H, Cliff J, Pratt HL, Stevens J. 2000. Reproductive biology of the female shortfin mako, Isurus oxyrinchus Rafinesque, 1810, with comments on the embryonic development of Lamnoids. Fish. Bull. 98(2): 299-318.

Musick JA. 1999. Life in the Slow Lane: Ecology and Conservation of Long-Lived Marine Animals. In: Musick JA (ed.), Proceedings of the Symposium Conservation of Long-Lived Marine Animals; 24 August 1997; Monterey, California (USA). Am. Fish. Soc., Bethesda (MD), pp. 1-9.

Nezlin NP, Oram JJ, DiGiacomo PM, Gruber N. 2004. Sub-seasonal to interannual variations of sea surface temperature, salinity, oxygen anomaly, and transmissivity in Santa Monica Bay, California from 1987 to 1997. Cont. Shelf Res. 24(10): 10531082. http://dx.doi.org/10.1016/j.csr.2004.03.012

Pearse AGE. 1968. Histochemistry, theorical and applied. Churchill Livingstone, London, 1215 pp.

Pérez-Jiménez JC, Sosa-Nishizaki O. 2008. Reproductive biology of the Brown smoothhound shark. Mustelus henlei, in the northern Gulf of California, México. J. Fish Biol. 73(4): 782-792. http://dx.doi.org/10.1111/j.1095-8649.2008.01939.x

Pérez-Jiménez JC, Sosa-Nishizaki O. 2010. Determining reproductive parameters for population assessments of two smoothhounds (Mustelus californicus and Mustelus lunulatus) from the northern Gulf of California, México. Bull. Mar. Sci. 86(1): 3-13.

Pratt HL. 1993. The storage of spermatozoa in the oviducal glands of western North Atlantic sharks. Environ. Biol. Fishes 38(1-3): 139-149. http://dx.doi.org/10.1007/BF00842910

Pratt HL, Tanaka S. 1994. Sperm Storage in Male Elasmobranch: A Description and Survey. J. Morphol. 219(3): 297-308. http://dx.doi.org/10.1002/jmor.1052190309

Saïdi B, Bradaï MN, Bouaïn A. 2009. Reproductive biology and diet of Mustelus punctulatus (Risso 1826) (Chondrichthyes: Triakidae) from the Gulf of Gabès, Central Mediterranean Sea. Sci. Mar. 73(2): 249-258. http://dx.doi.org/10.3989/scimar.2009.73n2249

Sandoval-Castillo J, Beheregaray LB. 2015. Metapopulation structure informs conservation management in a heavily exploited coastal shark (Mustelus henlei). Mar. Ecol. Progr. Ser. 533: 191-203.

http://dx.doi.org/10.3354/meps11395 
Serra-Pereira B, Figueiredo I, Serrano-Gordo L. 2011. Maturation of the gonads and reproductive tracts of the thornback ray Raja clavata, with comments on the development of a standardized reproductive terminology for oviparous elasmobranchs. Mar. Coast. Fish.: Dynamics, Manage., Ecosyst. Sci. 3(1): 160-175.

http://dx.doi.org/10.1080/19425120.2011.555707

Sicard-González MT, Tripp-Valdéz MA, Ocampo L, MaedaMartínez AN, Lluch-Cota SE. 2012. Coastal sea surface temperature records along the Baja California península. Oceánides 27(2): 65-69.

Tanaka S, Mizue K. 1979. Studies on sharks-XV: age and growth of Japanese dogfish Mustelus manazo Bleeker in the East China Sea. Bull. Jap. Soc. Sci. Fish. 45: 43-50. http://doi.org/10.2331/suisan.45.43

Walker IT. 1998. Can shark resources be harvested sustainably? A question revisited with a review of shark fisheries. Mar. Freshwat. Res. 49(7): 553-572. http://dx.doi.org/10.1071/MF98017

Walker TI. 2005a. Reproduction in fisheries science. In: Hamlett WC (ed.), Reproductive Biology and Phylogeny of Chondrichthyes: Sharks, Batoids and Chimaeras. Science Publishers, Enfield (NH), pp. 81-127.

Walker TI. 2005b. Management measurements. In: Musick JA, Bonfil R (eds.), Management techniques for elasmobranch fisheries. Food and Agriculture Organization of the United Nations, Rome (Italy), pp. 216-242.

Walker IT. 2007. Spatial and temporal variation in the reproductive biology of gummy shark Mustelus antarcticus (Chondrichthyes: Triakidae) harvested off southern Australia. Mar. Freshwat. Res. 58(1): 67-97. https://doi.org/10.1071/MF06074

Walmsley-Hart SA, Sauer WHH, Buxton CD. 1999. The biology of the skates Raja wallacei and R. pullopunctata (Batoidea: Rajidae) on the Agulhas Bank, South Africa. S. Afr. J. Mar. Sci. 21: 165-179. http://dx.doi.org/10.2989/025776199784126051

Yamaguchi A, Taniuchi T, Shimizu M. 2000. Geographic variations in reproductive parameters of the starspotted dogfish, Mustelus manazo, from five localities in Japan and in Taiwan. Enviroment. Biol. Fishes 57(2): 221-233. http://dx.doi.org/10.1023/A:1007558324902

Yudin KG, Cailliet GM. 1990. Age and growth of the gray smoothhound, Mustelus californicus, and the Brown smoothhound, $M$. henlei, sharks from Central California. Copeia 1990 (1): 191-204. http://dx.doi.org/10.2307/1445835

Received March 2017, accepted February 2018. 